\title{
ERB-38 Immunotoxin
}

National Cancer Institute

\section{Source}

National Cancer Institute. ERB-38 Immunotoxin. NCI Thesaurus. Code C2453.

A bivalent fusion protein consisting of disulfide-stabilized Fv fragments of an anti-HER2 (erbB2) monoclonal antibody (e23) and a truncated version of the $M(r) 38$ fragment of Pseudomonas exotoxin that lacks the toxin's cell binding domain. ERB-38 immunotoxin binds specifically to cells that overexpress HER2, the antigenic target of the monoclonal antibody; the exotoxin portion of the immunotoxin then lyses the cells bound by the antibody portion. ( $\mathrm{NCl} 04)$ 